\title{
RENT SEEKING DAN PRAKTIK KORUPSI DI TUBUH BUMD: KASUS BUMD PT BANTEN GLOBAL DEVELOPMENT (BGD)
}

\author{
Mahpudin a dan Yugni Maulana Aziz ${ }^{\mathrm{b}}$ \\ aurusan Politik Pemerintahan Universitas Gadjah Mada, \\ ${ }^{\mathrm{b} J u r u s a n}$ Ilmu Pemerintahan Universitas Sultan Ageng Tirtayasa \\ E-mail: Mahpudin95@mail.ugm.ac.id ; yugni@fisip-untirta.ac.id
}

\begin{abstract}
ABSTRAK. Artikel ini membahas tentang praktik rent seeking di tubuh Badan Usaha Milik Daerah (BUMD) spesifik pada PT Banten Global Development (BGD) sebagai perusahaan milik Pemerintah Provinsi Banten. Alih-alih memberi kontribusi terhadap Pendapatan Asli Daerah (PAD) dan pembangunan di Banten, PT BGD justru hanya menjadi alat perburuan rente antara state actor dan economic actor dengan memanfaatkan sumber daya keuangan yang dimiliki pemerintah untuk kepentingan ekonomi politik segelintir elit. Artikel ini berusaha memetakan pola rent seeking yang bekerja dibalik pengelolaan perusahaan PT BGD. Metode kualitatif dipilih dalam penelitian ini, adapun pengumpulan data dilakukan melalui studi literatur terhadap berbagai bahan bacaan yang relevan. Hasil penelitian menunjukkan bahwa pembentukan PT BGD menciptakan korupsi pada perusahaan pemerintah melalui praktik rent seeking. Pola rent seeking yang terbentuk adalah "rent seizing” yaitu state actors berusaha mendapatkan hak mengalokasikan rente yang dihasilkan dari institusi pemerintah untuk kepentingan individu dan kelompoknya. Di sisi lain, pihak perusahaan (economic actor) memperoleh keuntungan dari kebijakan yang dibuat oleh elit politik dengan cara menyuap dan cara-cara lain yang melanggar konstitusi. Pihak perusahaan yang dimaksud tidak merujuk pada perusahaan swasta melainkan perusahaan milik pemerintah yaitu BUMD PT BGD.
\end{abstract}

Kata kunci: Rent seeking; Korupsi; BUMD

ABSTRACT. This article discusses the practice of rent-seeking within the Provincial Government-Owned Company (BUMD), specifically at PT Banten Global Development (BGD) as a company owned by the Banten Provincial Government. Instead of contributing to Regional Original Income (PAD) and development in Banten, PT BGD has only become a rentseeking tool between state actors and economic actors by utilizing financial resources owned by the government for the interests of the political economy of a handful of elites. This article attempts to map the rent-seeking patterns that work behind the management of the PT BGD company. The qualitative method was chosen in this study, while data collection was carried out through literature studies of various relevant reading materials. The results showed that the formation of PT BGD created corruption in government enterprise through rent-seeking. The rent-seeking pattern formed is "rent seizing," namely state actors trying to get the right to allocate rent generated from government institutions for the interests of individuals and groups. On the other hand, the company (economic actor) benefits from the political elite's policies through bribes and other means that violate the constitution. The company does not refer to a private but a governmentowned company, namely BUMD PT BGD.

Keywords: Rent seeking; Corruption; BUMD

\section{PENDAHULUAN}

Penyebab buruknya kualitas layanan publik dan pengelolaan potensi di daerah salah satunya tidak lepas dari relasi bisnis dan politik (Saleh \& Perdana, 2009). Relasi ini menghasilkan praktik rent seeking (perburuan rente). Rent seeking menjadi akar masalah dari munculnya korupsi sebab praktik ini memberi peluang terciptanya manipulasi kebijakan sebagai implikasi dari kesepakatan dan lobby politik di luar struktur lembaga formal (Hogan et al., 2011:102-113). Tidak hanya melanggar aturan, tetapi justru aturan tersebut dibuat secara legal untuk memuluskan praktek perburuan rente. Praktik rent seeking menabrak logika good governance yang mana sebuah instansi publik seharusnya mampu mengedepankan transparansi, akuntabilitas, dan partisipasi (Grafton \& Williams, 2020).

Relasi antara bisnis dan politik menghasilkan tiga tipe praktik rent seeking sebagaimana digagas oleh Ross (2001), pertama, rent creation yaitu perusahaan mencari keuntungan yang dibuat oleh pemerintah dengan cara menyuap politisasi atau birokrat. Kedua, rent seizing adalah kondisi ketika aktor-aktor pemerintah atau birokrat berusaha mendapatkan hak mengalokasikan rente yang dihasilkan dari institusi-institusi negara untuk kepentingan individu dan kelompoknya. Ketiga, rent extraction, dimana politisi dan birokrat mencari keuntungan dari perusahaan dengan mengancam perusahaan melalui peraturan-peraturan.

Pertautan antara bisnis dan politik menjadi salah satu penyebab munculnya praktik korupsi yang menjelaskan bahwa korupsi tidak lagi hanya dipandang sebatas pada perilaku buruk yang melibatkan aktor yang ada dalam institusi pemerintah, tetapi juga mencakup ruang yang lebih luas yaitu antara penguasa dan pengusaha dalam mendistribusikan sumber daya milik negara. Hal ini sebagaimana argumen Lambsdorff (2002: 104) 
bahwa perilaku rent seeking dapat digolongkan sebagai tindak korupsi pada saat kesempatan lobi tidak ditransparansikan ke publik, jadi hanya pihakpihak tertentu yang dapat terlibat kompetisi. Praktek rent seeking ini merupakan akar dari munculnya korupsi, dimana pola relasi pebisnis yang memburu rente dengan pemerintah yang membuat kebijakan, dalam prosesnya banyak menghasilkan kesepakatan yang berada di luar struktur lembaga formal. Singkat kata, rent seeking dan korupsi adalah dua entitas yang saling terkait. Boleh dikatakan bahwa rent seeking merupakan salah satu bentuk korupsi yang terjadi pada institusi publik dengan melibatkan aktor negara sebagai pemain utama.

Berdasarkan ulasan tersebut, kita dapat menarik suatu pemahaman bahwa sebuah tindakan dapat dikatakan mengarah pada praktik rent seeking yaitu adanya penyalahgunaan kekuasaan oleh pejabat politik atau birokrat untuk mendapatkan sumber daya negara dengan memanipulasi aturan dan kebijakan bahkan tidak hanya melanggar aturan melainkan justru aturan tersebut dibuat secara legal untuk memuluskan praktek perburuan rente. Karakter rent seeking adalah mengabaikan prinsip transparansi dan akuntabilitas sehingga berdampak pada terpinggirkannya kepentingan publik. Tata kelola pelayanan publik menjadi buruk (bad governance) dan berpeluang menciptakan praktik korupsi.

Praktik rent seeking dapat ditemukan pada banyak aspek termasuk salah satunya dalam pengelolaan perusahaan milik daerah (BUMD). Pada dasarnya, BUMD didirikan dengan dua tujuan utama, yaitu sebagai penopang untuk menambah pemasukan anggaran pemerintah sehingga dapat membantu memaksimalkan implementasi kegiatan dan program pemerintah yang memerlukan biaya besar. Hadirnya pemasukan anggaran pemerintah juga sebagai upaya meminimalisir ketergantungan anggaran terhadap pemerintah pusat. Tujuan lain dari eksistensi BUMD untuk membantu mempermudah pemerintah dalam memberikan pelayanan kepada masyarakat. Namun, dalam perkembangannya, BUMD dijadikan sebagai instrumen untuk memperoleh keuntungan material secara ilegal oleh segelintir elit berkepentingan (Iskandar \& Kurniawan, 2020)

Artikel ini berusaha menganalisis praktik korupsi sebagai implikasi dari praktik rent seeking dalam pengelolaan BUMD di Provinsi Banten yaitu PT Banten Global Development (BGD). Sejak awal, pendirian PTBGD sempat dipertanyakan oleh banyak pihak sebab pembentukan badan usaha ini tidak ditopang oleh legal standing yang kuat. Di samping itu, terdapat indikasi yang kuat bahwa terdapat upaya untuk memanfaatkan APBD Banten dengan dalih pembentukan PT BGD sebagai perusahaan milik pemerintah. Hal ini diperkuat dengan kenyataan bahwa selain perusahaan ini bermasalah dan terus mengalami kerugian, ada kaitannya dengan kepentingan pragmatis elit politik yang mana jajaran pimpinan PT BGD selalu mengalami perombakan ketika terjadi pergantian kepemimpinan kepala daerah (Bantenhits.com, 2015).

Studi mengenai rent seeking yang melibatkan tindakan korupsi oleh pejabat publik telah banyak dikaji. Studi Saleh \& Perdana (2009) mengkaji praktik rent seeking dalam kasus Pemberian Izin Usaha Pertambangan Nikel di Provinsi Sulawesi Tenggara. Praktik korupsi ini melibatkan Gubernur Sulawesi Tenggara, Nur Alam dan pihak swasta yang berkecimpung dalam usaha di bidang pertambangan. Bentuk rent seeking tidak mengarah pada state capture, melainkan interaksi yang saling menguntungkan antara penguasa dan pengusaha dalam praktik suap kebijakan kemudahan izin usaha.

Studi Evaquarta (2010) melakukan perbandingan di Kota Batam dan Kabupaten Kutai Kartanegara dalam memotret hubungan antara elit politik dan ekonomi yang membentuk praktik rent seeking. Evaquarta mengaitkan praktik rent seeking sebagai implikasi dari kebijakan desentralisasi politik di tingkat lokal. Kota Batam menunjukkan hadirnya persaingan dalam memperebutkan dominasi kekuasaan diantara banyak kelompok kepentingan seperti pejabat birokrat dan DPRD. Mereka bersaing membentuk relasi dengan elit ekonomi lokal untuk tujuan perburuan rente.

Studi yang dihasilkan oleh Syamsuddin et al., (2019) mengungkap korupsi kebijakan pendirian BUMD Kota Batu yaitu PT BWR (Batu Wisata Resource). Kasus ini melibatkan tiga aktor yaitu kepala daerah, direktur PT BWR dan pengusaha terkenal di Kota Batu. Praktik korupsi berupa penggelapan keuangan yang dimiliki PT BWR dan pemberian kemudahan melalui regulasi dan kebijakan yang dikeluarkan oleh pemerintah Kota Batu seperti keringanan pajak dan izin pendirian usaha pariwisata kepada beberapa pengusaha lokal yang memiliki relasi dengan kepala daerah.

Studi Iskandar \& Kurniawan (2020) menyoroti potensi terjadinya korupsi di badan usaha milik pemerintah (BUMN/BUMD) karena praktik kecurangan berupa gratifikasi. Gratifikasi terjadi pada pimpinan atau pegawai perusahaan pemerintah yang mendapat pemberian dari pihak lain (aktor negara maupun aktor swasta) berupa barang atau dalam bentuk lainnya untuk tujuan ekonomi politik tertentu.

Berdasarkan uraian literatur ini, dapat dilihat bahwa praktik rent seeking menjadi sebuah keniscayaan yang tidak dapat dihindari sebagai konsekuensi dari hadirnya kekuasaan dan wewenang yang melekat pada pejabat publik. Di samping itu, 
rent seeking terjadi pada banyak arena institusi publik dan melibatkan banyak aktor. Dalam artikel ini, penulis berupaya memperkuat temuan studi yang telah ada terkait rent seeking dengan menekankan praktik korupsi pada "government enterprise" sebagai salah satu preferensi lain dari relasi antara state actor dan economic actor. Kasus penelitian ini adalah PT Banten Global Development (BGD), sebagai perusahaan milik Pemerintah Provinsi Banten (Pemprov). Kajian ini menjadi penting untuk diteliti lebih lanjut karena PT BGD memiliki berbagai persoalan dalam tata kelola perusahaan dan konflik kepentingan. Meskipun PT BGD mengalami kerugian, tetapi sampai saat ini keberadaannya masih dipertahankan sebab terdapat praktik rent seeking yang terus dipelihara oleh aktor yang berkepentingan. Secara spesifik, artikel ini berusaha menjawab pertanyaan bagaimana bekerjanya praktik rent seeking dalam pengelolaan PT BGD sebagai BUMD milik Provinsi Banten. Artikel ini berargumen bahwa terdapat upaya memanfaatkan APBD Banten dengan modus mendirikan BUMD Banten melalui PT BGD. Implikasinya, PT BGD menjadi lahan yang subur untuk melayani kepentingan segelintir kelompok melalui praktik rent seeking. Praktik rent seeking menjadi penyebab terjadinya bad governance dalam tubuh BUMD yang berujung pada tindakan korupsi. Sementara fungsi pelayanan publik dan kepentingan publik semakin terpinggirkan.

\section{METODE}

Artikel ini menggunakan jenis penelitian kualitatif untuk menggambarkan dan memahami praktik rent seeking yang berujung pada tindakan korupsi dalam pengelolaan perusahaan milik daerah, spesifik PT BGD. Pendekatan kualitatif dipilih karena mampu menjawab kebutuhan penelitian ini sebagai upaya untuk mendapatkan pemahaman terhadap sebuah fenomena secara mendalam dan komprehensif. Adapun pendekatan kualitatif yang dipakai adalah analisis deskriptif. Mengacu pada pendapat Nazir (2003), tujuan dari analisis deskriptif adalah untuk menggali, memahami, dan menganalisis data dan fakta-fakta dengan interpretasi yang tepat.

Proses pengumpulan data dilakukan menggunakan data sekunder melalui studi literatur yang relevan dalam membedah praktik rent seeking dalam pengelolaan di tubuh perusahaan milik pemerintah. Literatur yang dimaksud berupa bahan bacaan dalam berbagai macam seperti buku, jurnal, artikel. Sementara data informasi terkait dengan diskursus rent seeking dan korupsi di PT BGD mengacu pada informasi yang tersedia di media online baik nasional maupun lokal seperti Kompas.com, Detik. com, Tempo.co, Radarbanten.co.id, Kabarbanten. com dan berita online lainnya yang relevan dalam studi ini. Sementara teknik analisis data dilakukan dengan memfokuskan perhatian pada organisasi data, membuat catatan spesifik sebagai bahan untuk melakukan deskripsi, klasifikasi dan interpretasi data (Creswell, 2014).

\section{HASIL DAN PEMBAHASAN}

\section{Cacat Sejak Lahir: Awal Pembentukan PT BGD sebagai BUMD Banten}

BGD awalnya masih berstatus sebagai Perusahaan Daerah (PD), sebelum menjadi Perusahaan Terbatas (PT). Motif dasar Pemerintah Provinsi (Pemprov) Banten mendirikan perusahaan plat merah ini adalah melakukan terobosan dalam tata kelola pemerintahan dengan menawarkan konsep "entrepreneurship government" yang berarti ter-dapat semangat menumbuhkanjiwa wirausaha di lingkungan Pemprov Banten (Jauhar, 2015). Untuk membuat langkah yang nyata, political will tersebut ditopang melalui sebuah peraturan daerah (Perda) sebagai legal standing pembentukan perusahaan daerah. Perda yang dimaksud adalah Perda Banten Nomor 54 Tahun 2002 tentang Pembentukan Perusahaan Daerah yang disahkan pada masa kepemimpinan Munandar sebagai Gubernur Banten. Dalam Perda tersebut sedikitnya terdapat tiga tujuan pembentukan Perusahaan Daerah yaitu: pertama, menyelenggarakan usaha untuk menyediakan kemanfaatan umum berupa penyediaan barang dan atau jasa yang bermutu tinggi dan terjangkau oleh masyarakat. Kedua, mendorong pertumbuhan perekonomian kerakyatan di Daerah. Ketiga, memupuk keuntungan yang wajar guna peningkatan nilai perusahaan dan peningkatan pendapatan asli Daerah.

Pasca Perda tersebut ditetapkan, Pemprov Banten mengeluarkan Keputusan Gubernur (Kepgub) Banten Nomor 9 tahun 2003 tentang Perusahaan Daerah Banten Global Development Banten. Hal ini menjadi titik awal bagi Pemprov memiliki perusahaan daerah. BGD bergerak dalam bidang usaha investasi dan mengontrol kepemilikan saham. Meskipun sekilas nampak bahwa pembentukan BGD tidak bermasalah sebab memiliki legal standing yang jelas, namun jika ditelusuri lebih mendalam ternyata terdapat kejanggalan. Dalam Perda tersebut tidak mengatur bagaimana pola pengawasan yang dilakukan oleh Pemprov Banten terhadap perusahaan daerah yang dalam hal ini adalah BGD. Selain itu, Perda tersebut juga sama sekali tidak mengatur perihal syarat dan kriteria pembentukan perusahaan termasuk prosedur dalam memberikan penyertaan modal baik terhadap perusahaan yang sudah ada atau perusahaan yang 
dibentuk sendiri oleh Pemprov Banten. Sementara, pembentukan BGD melalui Kepgub bertentangan dan melanggar Undang-undang Nomor 54 Tahun 1962 tentang Perusahaan Daerah yang mengatur bahwa perusahaan daerah didirikan melalui Perda. Dengan kata lain, pembentukan BGD sebagai perusahaan daerah seharusnya disahkan melalui Perda bukan Kepgub. Artinya, pembentukan BGD dapat dikatakan cacat hukum.

Beberapa aktivis turut mengkritik pembentukan BGD, salah satunya adalah aktivis yang tergabung dalam Koalisi Masyarakat Penyelamat Aset dan Keuangan Banten (KOMPAK Banten). Mereka menilai bahwa pembentukan BGD tanpa melalui Perda menunjukkan bahwa Pemprov dan DPRD Banten ingin menghindari proses perumusan kebijakan yang panjang dan lama dengan pertimbangan bahwa satu Perda untuk setiap perusahaan daerah (Jauhar, 2015). Padahal, dalam amanat Undangundang Nomor 54 Tahun 1962 menyebut bahwa setiap perusahaan daerah harus ditopang oleh Perda khusus. Dengan kata lain, Pemprov dan DPRD Banten berusaha memangkas prosedur dan aturan perumusan kebijakan.

Selain itu, KOMPAK Banten juga menyoroti bahwa BGD tidak memiliki core business yang jelas melainkan hanya bergerak dalam memberikan modal kepada perusahaan lain. Implikasinya, pembentukan BGD diduga sarat dengan konflik kepentingan pejabat politik yaitu memanfaatkan APBD Banten untuk kepentingan politik pragmatis dengan modus mendirikan badan usaha milik pemerintah (Jauhar, 2015).

Berdasar pada persoalan ini, maka terdapat tiga hal penting yang menjadi perhatian: pertama, pembentukan BGD tanpa Perda melainkan hanya dengan Kepgub mengindikasikan bahwa terdapat relasi kekuasaan yang tidak seimbang antara eksekutif dan legislatif yang mana dalam pembentukan BGD kekuasaan eksekutif tampil lebih dominan melampaui legislatif atau relasi keduanya justru dibangun secara kooperatif namun bersifat oportunis dan pragmatis untuk mengeksploitasi sumber daya negara. Kedua, pembentukan BGD dilakukan secara tergesa-gesa tanpa mempertimbangkan payung hukum yang kuat dan komprehensif. Ketiga, pembentukan BGD berpotensi hanya dijadikan sebagai instrumen untuk melayani kepentingan ekonomi politik elit tertentu.

Mendapat kritikan publik terkait pembentukan BGD yang cacat hukum, Pemprov Banten dan DPRD kemudian mengeluarkan Perda Nomor 7 tahun 2009. Melalui Perda ini pula status BGD berubah dari semula bersifat Perusahaan Daerah menjadi Perseroan Terbatas. Dengan dikeluarkannya Perda tersebut, maka problem legal standing pembentukan perusahaan milik daerah teratasi. Sampai tahun 2015, PT BGD telah memiliki 11 anak perusahaan dan 9 Kerja Sama Operasional (KSO). Berikut rinciannya:

Tabel 1. Daftar Anak Perusahaan PT BGD

\begin{tabular}{cl}
\hline No & \multicolumn{1}{c}{ Anak Perusahaan } \\
\hline 1. & PT Banten Inti Gasindo \\
2. & PT Banten Global Synergi \\
3. & PT Banten Gas Synergi \\
4. & PT BJB Syariah \\
5. & PT Indo Biofuels Energy \\
6. & PT Banten Inti Gasindo \\
7. & PT Banten Global Synergi \\
8. & PT Duta Bandara Banten \\
9. & PT Banten Global Travel \\
10. & PT Banten Global Edukasi \\
11. & Jaminan Kredit Daerah (Jamkrida) \\
\hline
\end{tabular}

Sumber: Diolah oleh peneliti dari berbagai sumber

Tabel 2. Daftar Kerjasama Operasional dengan PT BGD

\begin{tabular}{cll}
\hline No & Kerja Sama Operasional & Besaran Penyertaan Modal \\
\hline 1. & Warehouse & (data tidak tersedia) \\
2. & Batu Split & 1,12 Miliar \\
3. & Slag Steel & 1,4 Miliar \\
4. & Tanah & 4 Miliar \\
5. & Briket & 10 Miliar \\
6. & Pasir Laut & 1 Miliar \\
7. & Kapal Tongkang & 2,5 Miliar \\
8. & Tambak Udang & 0,36 Miliar \\
9. & Batching Plant & 1 Miliar \\
\hline
\end{tabular}

Sumber: Sumber: Diolah oleh peneliti dari berbagai sumber

Data jumlah anak perusahaan PT BGD dan KSO sangat dinamis yang mana setiap tahun mengalami penambahan atau pengurangan sesuai dengan polemik yang dihadapi. Namun, sifat yang dinamis ini sesungguhnya menunjukkan kebobrokan dalam pengelolaan di PT BGD. Alih-alih mampu menambah pemasukan kas daerah, justru yang terjadi sebaliknya yaitu kerugian anggaran negara karena bisnis usaha berikut pengelolaannya tidak dijalankan secara profesional dan akuntabel. Hal ini diperkuat oleh pernyataan Ade Hidayat, wakil ketua DPRD Provinsi Banten bahwa kepemilikan saham BUMD PT BGD di sejumlah perusahaan tidak jelas kondisi dan keberadaannya sehingga tidak dapat dipastikan apakah keberadaan saham tersebut memberi kontribusi positif terhadap Pemprov Banten (Faktabanten.co.id, 2020).

Berangkat dari penjelasan ini, maka pembentukan PT BGD dapat dikatakan sudah cacat sejak lahir terutama terkait dengan legal standing. Implikasinya, keberadaan perusahaan milik pemerintah ini cenderung lebih dominan ditopang oleh kepentingan ekonomi politik dibanding kepentingan publik. PT BGD menjadi lahan yang subur bagi segelintir elit untuk mencari rente sebagaimana akan sangat nampak terlihat pada bagian pembahasan selanjutnya. 


\section{Berbagai Kerugian APBD Banten dan Kejanggalan di PT BGD}

Praktik perburuan rente di PT BGD dapat dilihat dengan mengacu pada kondisi dan situasi yang dihadapi PT BGD sejak awal pendirian hingga saat ini. Terdapat kerugian dan ketidakjelasan anggaran atau modal yang dimiliki PT BGD. Tabel dibawah ini menyajikan informasi terkait penyertaan modal dari Pemprov Banten ke PT BGD menggunakan APBD Banten.

Tabel 3. Penyertaan Modal dari Pemprov Banten Ke PT BGD

\begin{tabular}{cll}
\hline Tahun & $\begin{array}{c}\text { Jumlah Penyertaan } \\
\text { Modal Dari Pemprov } \\
\text { Banten Ke BGD }\end{array}$ & \multicolumn{1}{c}{ Dasar Hukum } \\
\hline 2007 & 1,5 Miliar & Perda Nomor 3 Tahun 2007 \\
2008 & 10,5 Miliar & Perda No 16 Tahun 2008 \\
2010 & 1,5 Miliar & Tidak ada \\
2011 & 9,5 Miliar & Tidak ada \\
2012 & 14,6 Miliar & Perda Nomor 1 Tahun 2012 \\
2013 & 950 Miliar & Perda No 5 Tahun 2013 \\
\hline
\end{tabular}

Sumber: Sumber: Diolah oleh peneliti dari berbagai sumber

Penyertaan modal dari Pemprov Banten ke PT BGD pertama kali dilakukan pada tahun 2007. Mengacu pada tabel di atas, hampir setiap tahun anggaran, Pemprov Banten menganggarkan penyertaan modal ke PT BGD dengan jumlah yang bervariatif. Jumlah modal yang terbilang cukup besar seolah ingin mempertegas keseriusan pemerintah mengembangkan BUMD. Namun, apabila dicermati lebihjauh, terdapat masalah dalam kegiatan penyertaan modal ini. Hal yang paling nampak adalah tidak semua kegiatan penyertaan modal dari Pemprov ke PT BGD memiliki payung hukum yang legal. Terhitung, dua kali Pemprov Banten menganggarkan dana ke PT BGD tanpa Perda yaitu pada tahun 2010 dengan jumlah modal yang diberikan sebesar 1,5 Milyar dan pada tahun 2011 sebesar 9,5 Milyar.

Penyertaan modal menggunakan anggaran pemerintah tanpa didasarkan pada payung hukum yang jelas telah melanggar aturan mengenai tata kelola keuangan. Peraturan Pemerintah (PP) Nomor 58 Tahun 2005 tentang Pengelolaan Keuangan Daerah secara eksplisit menyebut bahwa penyertaan modal daerah dapat direalisasikan apabila telah ditetapkan dalam sebuah Perda mengenai penyertaan modal daerah. Pemprov Banten menggelontorkan modal ke PT BGD menggunakan APBD Banten tanpa Perda di tahun 2010 dan 2011 mengindikasikan bahwa terdapat kejanggalan yang secara sengaja didesain untuk memanfaatkan anggaran daerah yang dimanfaatkan oleh segelintir elit berkepentingan. Bagaimana mungkin anggaran daerah dapat direalisasikan tanpa adanya dasar hukum yang jelas berupa Perda. Sementara Perda merupakan produk hukum atas dasar negosiasi dan kesepakatan politik antara DPRD dan kepala daerah. Artinya, dapat dikatakan bahwa penyertaan modal tersebut ilegal dan sarat dengan konflik kepentingan.

Absennya Perda yang mengatur penyertaan modal ke PT BGD selama dua kali berturut-turut menunjukkan bahwa tidak bekerjanya fungsi DPRD Banten dalam melakukan pengawasan terhadap eksekutif. DI saat yang bersamaan, hal tersebut menunjukkan hadirnya dominasi kekuasaan gubernur sebagai kepala pemerintah daerah dalam mengelola keuangan daerah (APBD). Atau dapat diduga bahwa sebenarnya justru DPRD dan eksekutif sama-sama menyadari hal tersebut untuk bergotong-royong berburu rente terhadap APBD Banten dengan dalih penyertaan modal.

Dugaan hadirnya praktek perburuan rente diperkuat dengan temuan bahwa berdasarkan pemeriksaan BPK pada tahun 2012, laporan modal Pemprov Banten diPTBGD dalamkurun waktu tahun 2007-2013 tercantum sebesar Rp. 34.961.227.000 sesuai dengan hasil RUPS (Rapat Umum Pemegang Saham). Akumulasi modal tersebut tidak sesuai dengan besaran modal yang sebenarnya yaitu sebesar Rp. 49,600.000.000. Artinya terdapat 4,6 Milyar APBD Banten di PT BGD yang hilang tanpa keterangan yang dapat dipertanggung jawabkan (Beritasatu.com, 2015c)

Penyertaan modal ke PT BGD menggunakan APBD Banten yang dilakukan pada periode tahun 2007-2013 merupakan era kekuasaan politik Ratu Atut Chosiyah yang menjabat sebagai Gubernur Banten dua periode (2006-2011 dan 2012-2017). Sebagaimana diketahui, Atut suskes membangun dinasti politik yang sangat kuat di Banten (Agustino, 2010; Hamid, 2014). Selama dua periode kekuasaan tersebut, Atut selalu mendapat dukungan mayoritas partai politik di DPRD (Mahpudin, 2018). Implikasinya, proses negosiasi politik di DPRD tidak menemukan hambatan yang berarti dalam upaya pembentukan Perda dan pengelolaan anggaran daerah termasuk menjalankan berbagai keputusankeputusan strategis tanpa pengawasan yang kuat dari DPRD. Pembentukan dan pengelolaan BUMD PT BGD menjadi salah satu contoh nyata dimana beberapa kejanggalan dalam pembentukan perusahaan daerah tersebut tidak lepas dari konflik kepentingan penguasa.

Karena sejak awal pendirian PT BGD ditemukan berbagai kejanggalan yang diduga kuat sebagai upaya perburuan rente, maka perkembangan berjalannya roda perusahaan di PT BGD tidak kunjung memuaskan. Performa kinerja PT BGD belum menghasilkan tanda-tanda kebermanfaatan bagi masyarakat Banten. Pembentukan PT BGD yang tidak profesional menyebabkan manajemen tata kelola di BGD menjadi buruk yang berdampak pada berbagai kerugian yang terus dihadapi. 
Mengacu pada Laporan Hasil Pemeriksaan BPK terhadap APBD Provinsi Banten tahun anggaran 2014, menyebut bahwa sejak pertama kali berdiri hingga tahun 2014, PT BGD selalu mengalami kerugian hingga 19 Miliar lebih (Bantenhits.com, 2015). Berikut rinciannya.

\section{Tabel 4. Kerugian PT BGD}

\begin{tabular}{cl}
\hline Tahun & \multicolumn{1}{c}{ Jumlah Kerugian } \\
\hline 2007 & Rp. $969.110 .965,-$ \\
2008 & Rp. 576.029.164,- \\
2009 & Rp. 2.259.334.596,-- \\
2010 & Rp. 1.688.998.284,-- \\
2011 & Rp. 3.494.821.720,- \\
2012 & Rp. 3.416.344.032,-- \\
2013 & Rp. 4.830.056.652,- \\
2014 & Rp. 2.693.133.476,- \\
Total Kerugian & Rp. 19.927.828.889,- \\
\hline
\end{tabular}

Sumber: Diolah oleh peneliti dari berbagai sumber

Persoalan di PT BGD terus menjadi perhatian publik ketika terdapat upaya pembentukan Bank Banten sebagai anak perusahaan PT BGD. Pembentukan Bank Banten sendiri merupakan amanat dari RPJMD Banten tahun 2012-2017 yang dirumuskan pada masa kepemimpinan Ratu Atut Chosiyah periode kedua. Alasan pembentukan Bank Banten adalah agar pemerintah Banten memiliki Bank secara mandiri sebab selama ini Banten masih menginduk ke BJB yang saham mayoritasnya dimiliki oleh Pemerintah Jawa Barat. Di atas kertas, pembentukan Bank Banten diharapkan dapat membantu perekonomian daerah dan mampu memberikan kontribusi terhadap PAD Banten yang digunakan untuk menopang pembangunan dan kesejahteraan masyarakat Banten (Suara.com, 2018).

Pembentukan Bank Banten sebagai anak perusahaan BGD alih-alih memberikan manfaat yang seluas-luasnya bagi kepentingan publik, justru menambah masalah baru. PT BGD sebagai perusahaan induk yang bertanggung jawab untuk mendirikan Bank Banten sebagaimana tertuang dalam Perda Nomor 5 Tahun 2013, ternyata tidak dapat menjalankan tugas tersebut secara profesional, akuntabel dan transparan yang mana sejak awal pendirian terdapat berbagai kejanggalan termasuk terus-menerus mengalami kerugian. Kejanggalan yang dimaksud misalnya terkait dengan penyertaan modal yang dianggarkan oleh Pemprov Banten kepada PT BGD untuk membentuk Bank Banten dimana modal awal yang diberikan sebesar $\mathrm{Rp}$. 314,60 Miliar pada tahun 2013.

Proses akuisisi Bank Banten menemukan hambatan sebab pada tahun tersebut, BPK merekomendasikan kepada Pemprov Banten agar menarik kembali dana tersebut ke kas daerah karena tidak sesuai ketentuan. Tidak hanya itu, persoalan lainnya adalah dana pembentukan Bank Banten pada saat diaudit oleh BPK ternyata hanya tersisa Rp. 300 M. Artinya, APBD Banten hilang tanpa jejak sebesar 14,6 Miliar (Beritasatu.com, 2015b). Kenyataan ini mendapat kritik yang tajam dari kalangan NGO seperti Lembaga Independen Peduli Publik (ALIPP) yang sangat kritis terhadap kebijakan di Banten. Sebagaimana pernyataan Uday Suhada selaku Direktur Eksekutif ALIPP sebagai berikut (Beritasatu.com, 2015a).

"Dana sebesar Rp. 314,6 Miliar itu patut dipertanyakan, karena dana tersebutsudah digelontorkan ke PT BGD sejak tahun 2013. Pertanyaannya, kemanakah bunga bank dana tersebut? Ini juga harus diusut oleh aparat penegak hukum dalam hal ini KPK. Bukan hanya itu, berdasarkan informasi yang diperoleh, ketika diaudit, dana $\mathrm{Rp} \mathrm{314,60}$ miliar itu berkurang dan hanya tersisa Rp 300 miliar. Sisanya dikemanakan? Ini pasti ada praktik korupsi di sana. Kami mendesak agar persoalan ini diusut tuntas."

Meskipun terdapat kejanggalan terkait dengan tidak jelasnya keberadaan dana APBD Banten di PT BGD, tetapi proses pembentukan Bank Banten tetap dilanjutkan dengan alasan merealisasikan RPJMD Provinsi Banten tahun 2012-2017. Proses akuisisi Bank mulai dinegosiasikan. Pada saat itu terdapat empat nama calon Bank untuk akuisisi sesuai dengan hasil kajian tim konsultan dari PT BGD. Empat Bank yang direkomendasikan yaitu Bank Panin Syariah, Bank MNC, Bank Windu, dan Bank Pundi. Pihak Pemprov Banten dan PT BGD bersepakat untuk mengakuisisi Bank Pundi menjadi Bank Banten. Bank Pundi adalah Bank milik Group Capital yang dimiliki oleh Sandiaga Uno (Gresnews.com, 2015).

Mengakuisisi Bank Pundi menjadi Bank Banten dinilai oleh aktivis Persatuan Urang Banten (PUG) sebagai sebuah keputusan yang ceroboh sebab Bank Pundi dilihat dari aspek kinerja perusahaan dianggap bukan Bank yang layak diakuisisi. Bahkan, Bank Pundi sudah diambang kehancuran dikarenakan kredit macet dan manajemen tata kelola perusahaan yang buruk (Wanmedia.co.id, 2020). Implikasinya, apabila Bank Pundi dipaksakan diakuisisi maka modal yang masuk berpotensi akan digunakan untuk memperbaiki manajemen terlebih dahulu untuk menutupi kerugian sehingga sulit membagikan keuntungan deviden kepada pemilik saham. Artinya, Pemprov Banten membeli Bank yang sedang sekarat. Atas dasar inilah, segenap masyarakat sipil banyak yang menolak keputusan Pemprov Banten dan PT BGD yang mengakuisi Bank Pundi (Wanmedia. co.id, 2020). Terkesan tidak mendengar kritik dan masukan dari masyarakat sipil, Pemprov Banten dan PT BGD tetap bersikukuh mengakuisisi Bank Pundi menjadi Bank Banten. 
Bank Banten kemudian secara resmi didirikan pada tahun 2016. Karena Pemprov Banten dan PT BGD membeli Bank yang sekarat ditambah dengan gagapnya pimpinan PT BGD dalam membenahi berbagai problem yang dihadapi Bank Banten, menyebabkan banyak kerugian setiap tahun. Berikut catatan kerugian Bank Banten selama 4 tahun terakhir sejak pertama kali dibentuk pada tahun 2016.

Tabel 5 Kerugian Bank Banten

\begin{tabular}{cl}
\hline Tahun & \multicolumn{1}{c}{ Total Kerugian } \\
\hline 2016 & Rp. 414,940 Miliar \\
2017 & Rp. 76,22 Miliar \\
2018 & Rp. 94,960 Miliar \\
2019 & Rp. 143,865 Miliar \\
2020 & Rp. 31,866 Miliar \\
\hline
\end{tabular}

Sumber: Diolah oleh Peneliti dari berbagai sumber

Berdasarkan informasi yang tersaji pada tabel diatas, maka nampak jelas bahwa pembentukan Bank Banten tidak memberikan manfaat apapun bagi pembangunan di Banten, alih-alih mampu berkontribusi terhadap pemasukan PAD dan menstimulus perekonomian masyarakat Banten, yang terjadi justru sebaliknya, Bank Banten hanya membebani APBD Banten. Bank Banten hanyalah salah satu potret kejanggalan yang terjadi di PT BGD. Hal serupa juga terjadi pada anak cabang perusahaan lainnya dibawah naungan PT BGD sebagai BUMD milik Pemprov Banten. Hal ini mempertegas bahwa terdapat permasalahan yang dihadapi PT BGD. Ironisnya, meski terus mengalami kerugian, jajaran direksi dan komisaris di BGD seringkali luput dari evaluasi Pemprov Banten dan DPRD Banten. PT BGD yang terbukti dengan jelas tidak membawa keuntungan dan perubahan yang lebih baik terhadap pembangunan di Banten, tetapi keberadaannya tetap dipertahankan oleh Pemprov Banten, semakin memperkuat indikasi bahwa PT BGD hanya menjadi alat bagi segelintir elit yang berkepentingan untuk memanfaatkan anggaran negara dengan modus membentuk BUMD (Jauhar, 2015).

\section{Praktik Korupsi di Tubuh BUMD}

Indikasi bahwa PT BGD semata-sama hanya melayani kepentingan segelintir elit dalam praktik perburuan rente terhadap sumber keuangan milik pemerintah tidak hanya nampak pada berbagai kerugian yang dihadapi PT BGD sepaket dengan berbagai kejanggalan termasuk hilangnya milyaran dana APBD Banten di PT BGD yang belum jelas keberadaannya. Ragam kasus praktik korupsi di PT BGD sebagai BUMD ini berkontribusi dalam memperkuat indikasi bekerjanya praktik rent seeking, berburu anggaran negara secara ilegal. Kasus korupsi yang berhasil mencuri perhatian publik terjadi pada kasus Bank Banten sebagai anak cabang perusahaan
PT BGD.

Sebagaimana telah disinggung pada uraian sebelumnya bahwa PT BGD ditunjuk oleh Pemprov Banten pada masa kepemimpinan Ratu Atut Chosiyah dan Rano Karno untuk membentuk Bank Banten sesuai dengan RPJMD. Ricky Tampinongkol sebagai Direktur PT BGD terus melakukan negosiasi dan komunikasi yang intensif kepada Pemprov Banten dan DPRD untuk mempermudah proses pembentukan Bank Banten terutama terkait dengan pembentukan Perda yang akan menjadi landasan hukum berdirinya Bank Banten. Proses pendirian Bank Banten memerlukan dana sebesar Rp. 950 Miliar yang berasal dari APBD Banten. Dana tersebut dicairkan dalam tiga tahap. Dari dana tersebut, sebanyak Rp 350 Miliar digunakan untuk pembelian Bank sementara sisa anggaran dilunasi berbarengan dengan pengesahan Raperda pembentukan Bank Banten (Gresnews.com, 2015).

Rencananya, Bank Banten akan secara resmi didirikan pada awal tahun tahun 2016 mengingat Perda yang diperlukan sebagai dasar hukum pembentukan Bank Banten sudah disahkan pada penghujung tahun 2015. Namun, tidak lama setelah Perda disahkan, KPK berhasil melakukan operasi tangkap tangan terhadap Direktur PT BGD dan dua orang anggota DPRD Banten yaitu SM Hartono dan Tri Satya Santosa. Berdasarkan hasil pemeriksaan KPK, Ricky Tampinongkol terbukti memberikan sejumlah uang sebesar 11.000 dollar dan Rp. 60 juta rupiah kepada Hartono dan Santosa. Pemberian sejumlah uang tersebut dilakukan berkali-kali. Kasus suap terjadi bersamaan dengan proses pengesahan Raperda pembentukan Bank Banten. Praktik korupsi ini dilakukan untuk mempermudah proses pengesahan APBD Banten terkait dengan dana yang akan dikucurkan ke PT BGD untuk membentuk Bank Banten (Beritasatu.com, 2015c).

Kasus korupsi lainnya di tubuh BUMD PT BGD terkait dengan Kerja Sama Operasional (KSO) PT BGD dengan PT Surya Laba Sejati (SLS). Pada tahun 2015, PT BGD memberikan pinjaman modal kepada PT SLS sebesar Rp. 5,19 Miliar untuk pengadaan proyek penambangan emas di wilayah Bayah, Kabupaten Lebak, Banten. Berdasarkan pada catatan perjanjian kerja sama, proyek tersebut akan selesai selama satu tahun. Namun sampai tahun 2016, proyek penambangan emas tidak pernah ada alias "proyek fiktif'. Sementara dana pinjaman yang telah diberikan oleh PT BGD tidak pernah dikembalikan oleh PT SLS. Atas dasar inilah, Kejaksaan Tinggi Negeri Serang menahan Ricky Tampinongkol selaku Direktur Utama PT BGD dan Ilham dari PT SLS karena terbukti melakukan korupsi dalam pemberian modal pinjaman menggunakan APBD Banten (Suarabanten.com, 2020). 
Tata kelola yang buruk di PT BGD ternyata juga terjadi pada KSO lainnya. PT BGD merupakan perusahaan yang bergerak dalam bidang permodalan. Melalui KSO, sejumlah dana yang berasal dari APBD dapat disalurkan kepada perusahaan lain milik swasta melalui skema kerja sama dengan menempatkan PT BGD sebagai investor. Namun dari sejumlah KSO yang dimiliki oleh PT BGD, kerja sama yang dibangun dengan berbagai perusahaan swasta tidak pernah ada kejelasan. Akuntabilitas pejabat di PT BGD terkait dengan pengelolaan keuangan sangat rendah. Hal ini diperburuk dengan sikap pemprov Banten dan DPRD Banten yang cenderung mengabaikan permasalahan tersebut. Implikasinya, senada dengan Bank Banten, KSO selain sebagai lahan korupsi, ternyata terbukti hanya menyumbang kerugian keuangan negara. Di tahun 2015 misalnya, 11 anak perusahaan BUMD PT BGD mengalami potential loss senilai Rp. 20,3 Miliar. Sementara, $36 \mathrm{KSO}$ yang dimiliki oleh Pemprov Banten saat ini terbukti sama sekali belum mampu memberikan kontribusi yang positif terhadap PAD Banten.

\section{Rent Seeking di Tubuh BUMD}

Berbagai kerugian keuangan negara yang bersumber dari APBD Banten dan praktik korupsi di tubuh PT BGD menyisakan pertanyaan besar bagaimana sesungguhnya praktik rent seeking bekerja pada perusahaan milik pemerintah. Artikel ini menunjukkan bahwa berbagai kasus korupsi dan kerugian keuangan negara adalah implikasi dari praktik rent seeking. Hal ini dapat dilihat dari hadirnya manipulasi kebijakan terkait pembentukan BUMD Banten dan penyertaan modal melalui negosiasi dan lobby politik secara informal.

Hal ini dipertegas dengan terungkapnya kasus korupsi yang melibatkan Direktur PT BGD Ricky Tampinongkol dengan dua anggota DPRD Banten, Hartono dan Santosa. Persekongkolan yang dilakukan oleh mereka berkaitan dengan manipulasi kebijakan terkait proses penyusunan APBD Banten dan perumusan Perda pembentukan Bank Banten.

Ironisnya, justruaturan(kebijakan) dibuatsecara legal untuk memuluskan praktik rent seeking. Hal ini dapat dilihat dari dibentuknya beberapa Perda terkait penyertaan modal kepada PT BGD menggunakan APBD Banten. Perda dibuat untuk memberi kesan bahwa pembentukan BUMD bersifat legal dan dapat dipertanggungjawabkan secara hukum. Padahal yang terjadi adalah sebaliknya, legalitas tersebut membuka peluang kepada segelintir elit politik dan ekonomi yang berada di lingkaran kekuasaan untuk meraup uang negara secara ilegal.

Argumen tersebut diperkuat oleh kenyataan bahwa PT BGD selalu merugi dan banyak dana yang keberadaannya tidak jelas. Implikasi dari praktik rent seeking ini telah menabrak logika good governance. Prasyarat good governance mencakup akuntabilitas, transparansi, penegakan hukum, dan partisipasi (Sedarmayanti, 2012:74). Namun, tata kelola PT BGD menunjukkan bad governance yang ditandai oleh tidak adanya akuntabilitas terhadap tata kelola keuangan yang dimiliki perusahaan PT BGD. Aspek transparansi belum nampak dalam hal informasi mengenai laporan keuangan, kegiatan ekonomi perusahaan, dan siapa saja aktor atau institusi yang berkepentingan dengan PT BGD. Selain itu terdapat kecenderungan bersikap abai karena kurang memberikan atensi yang serius terhadap masukan dari publik terutama kalangan civil society yang memiliki concern terhadap perkembangan PT BGD.

Kasus suap yang melibatkan Ricky Tampinongkol sebagai direktur PT BGD dan anggota DPRD Banten mempertegas bahwa terdapat pertautan yang saling berkelindan antara pengusaha dan penguasa untuk menciptakan praktik rent seeking. Sebagaimana diungkap oleh (Girling, 1997) bahwa relasi antara penguasa dan pengusaha bertujuan untuk mendistribusikan sumber daya milik negara secara ilegal melalui negosiasi politik. Ricky Tampinongkol sendiri dikenal sebagai salah satu pengusaha ternama di Banten. Ia tercatat sebagai Chief Executive Officer di PT Autocar Industri Komponen. Karena popularitasnya dalam dunia usaha menjadikan dirinya dipilih sebagai Direktur di PT BGD. Sementara dua anggota dewan, Hartono dan Santosa yang terlibat dalam kasus korupsi mewakili kalangan penguasa yang memiliki kekuasaan dalam menghasilkan keputusan politik. Hartono merupakan Wakil Ketua DPRD Banten sekaligus Ketua DPD Partai Golkar Kabupaten Serang. Ia juga tercatat sebagai anggota Dewan Penasihat Kamar Dagang dan Industri (KADIN) Banten. Sedangkan Santoso menjabat sebagai Ketua Fraksi PDI Perjuangan sekaligus anggota Komisi III yang membidangi urusan keuangan dan aset. Logika rent seeking yang bekerja pada kasus ini adalah DPRD memiliki kekuasaan menyusun APBD dan Perda Banten, berusaha melakukan agenda setting dengan memberikan kemudahan dalam proses perumusan kebijakan agar PT BGD memiliki legal standing yang kuat. Namun kemudahan tersebut akan dikompensasi menjadi keuntungan material dengan meminta suap kepada pimpinan PT BGD sebagai politik balas budi.

Praktik rent seeking dalam pembentukan BUMD PT BGD ternyata menciptakan relasi kuasa yang sangat kompleks tidak hanya melibatkan kekuasaan legislatif melalui oknum anggota dewan yang berusaha mencari peruntungan materi secara ilegal, tetapi juga terkait kekuasaan eksekutif. Artikel ini menemukan bahwa PT BGD sebagai lahan untuk 
melakukan distribusi sumber daya ekonomi politik menggunakan jejaring patronase. Ide pembentukan BUMD PT BGD pertama kali muncul pada masa kekuasaan Ratu Atut Chosiah. Atut sengaja menempatkan orang-orang yang selama ini dianggap loyal untuk menjadi bagian dari pimpinan PT BGD. Bahwa orang-orang yang menempati jabatan tertinggi di PT BGD terdiri dari mantan pejabat di Pemprov Banten yang juga berperan sebagai tim sukses Ratu Atut Chosiyah pada saat kontestasi elektoral di Pilkada Gubernur Banten tahun 2011. Hal ini sebagaimana pernyataan Uday Suhada, Direktur Eksekutif Lembaga Independen Peduli Publik (ALIPP) (Beritasatu.com, 2015a) sebagai berikut:

"Pemerintah Provinsi (Pemprov) Banten terkesan ngotot untuk mendirikan Bank Banten melalui BUMD yakni PT BGD yang sejak awal sudah menuai persoalan. Personel yang duduk sebagai pejabat teras di PT BGD pada saat awal terdiri atas mantan pejabat di lingkungan Pemprov Banten yang notabene merupakan tim sukses pasangan Ratu Atut Chosiyah-Rano Karno pada Pemilihan Gubernur (Pilgub) 2011 lalu.”

Salah satu loyalis Ratu Atut Chosiyah yang diangkat sebagai pejabat tertinggi di BUMD PT BGD adalah M Shaleh MT, mantan Kepala Dinas Bina Marga dan Tata Ruang (DBMTR) Provinsi Banten. Shaleh ditunjuk oleh Atut untuk menempati posisi sebagai Direktur Utama PT BGD. Selain itu, Atut juga menunjuk A Hilman Nitiamidjaja sebagai Komisaris Utama PT BGD. Hilman sendiri merupakan mantan Sekda Provinsi Banten (Gresnews.com, 2015). Kinerja PT BGD dibawah kepemimpinan orangorang yang menjadi loyalis Atut ini tidak memuaskan bahkan mengalami banyak permasalahan tata kelola keuangan seperti kondisi perusahaan yang terus merugi dan beberapa penyertaan modal yang bersumber dari APBD di PT BGD tidak jelas keberadaannya. Hal ini diperkuat oleh temuan dari LHP BPK pada tahun 2013 terkait dengan penyertaan modal sebesar 314,6 Miliar di BUMD PT BGD yang tidak bisa dipertanggungjawabkan. Begitu pula dengan hasil pemeriksaan DPRD Banten bahwa jajaran pimpinan di PT BGD dinilai tidak mampu bertanggungjawab atas keuangan yang dimiliki PT BGD (Beritasatu.com, 2015b). Tidak hanya itu, dibawah kepemimpinan Shaleh MT dan A Hilman Nitiamidjaja, PT BGD mengalami potensi kerugian senilai Rp. 20,3 M terkait dengan Kerja Sama Operasi (KSO) dalam sejumlah bidang usaha pada tahun 2014 (Gresnews.com, 2015)

Ketika Ratu Atut Chosiyah terjerat kasus korupsi dan dipenjara, jabatan gubernur diisi oleh Rano Karno yang sebelumnya menjabat sebagai wakil gubernur. Merespon berbagai permasalahan yang dihadapi BUMD PT BGD, Rano kemudian memecat seluruh jajaran direksi dan komisaris yang ditunjuk pada masa Ratu Atut berkuasa. Pada tahun 2014, Rano mengganti M Shaleh MT dengan Ricky Tampinongkol sebagai Direktur Utama di PT BGD, sementara A Hilman Nitiamidjaja digantikan oleh Indah Rusmiati sebagai Komisaris Utama (Gresnews. com, 2015). Perombakan struktur jabatan ini pada dasarnya tidak semata-semata ingin melakukan pembenahan tata kelola di BUMD PT BGD, tetapi terdapat kepentingan politis yaitu Rano ingin menyingkirkan loyalis Atut.

Menariknya, Indah Rusmiati merupakan mantan anggota DPRD Banten dari PDIP periode 2009-2014. Di saat yang bersamaan, Tri Satya Santosa adalah Ketua Fraksi PDIP sekaligus Pelaksana Harian di Badan Anggaran DPRD Banten. Rano Karno sendiri merupakan gubernur yang diusung oleh PDIP. Implikasinya, terdapat konflik kepentingan di tubuh BUMD PT BGD. PT BGD merupakan potret tarik menarik kepentingan politik. Kasus korupsi yang menyeret Ricky Tampinongkol dan Tri Satya Santosa terkait dengan suap Raperda pembentukan Bank Banten sebagai anak cabang perusahaan BUMD PT BGD mempertegas bahwa terdapat praktik perburuan rente di BUMD PT BGD.

Kepala daerah memiliki kekuasaan dan kewenangan yang mutlak untuk mengangkat dan memberhentikan jajaran direksi di BUMD. Hal tersebut sesuai dengan Undang-Undang Nomor 40 Tahun 2007 tentang Perseroan Terbatas bahwa pemilik saham berwenang mengangkat dan memberhentikan direksi. Sementara merujuk pada PP Nomor 58 Tahun 2005 menempatkan kepala daerah sebagai pemegang saham utama di BUMD. Dengan kata lain, utak-atik pengisian jabatan PTBGD sebagai BUMD milik Provinsi Banten adalah wewenang gubernur. Persoalannya adalah pengangkatan pejabat di BUMD cenderung bernuansa politis. Gubernur sebagai pejabat politik dalam menempatkan orangorang yang menjabat di PT BGD tidak berdasarkan pada prinsip merit system melainkan berdasar pada politik patronase sebagaimana telah dilakukan oleh Ratu Atut Chosiyah dan Rano Karno. Hal ini menjadi penyebab buruknya tata kelola BUMD PT BGD yang berujung pada tindakan korupsi.

Mengacu pada penjelasan tersebut maka tipe rent seeking sebagaimana digagas oleh Ross (2001) pada kasus ini adalah tipe "rent seizing" yaitu kondisi ketika aktor politik berusaha mendapatkan hak mengalokasikan rente yang dihasilkan dari institusiinstitusi negara dalam hal ini BUMD PT BGD untuk kepentingan individu dan kelompoknya. Disaat yang bersamaan, perusahaan memperoleh keuntungan dari kebijakan yang dibuat oleh elit politik dengan cara 
menyuap dan cara lain yang melanggar konstitusi. Namun perusahaan yang dimaksud dalam artikel ini tidak merujuk pada perusahaan swasta melainkan perusahaan milik pemerintah yaitu BUMD PT BGD. Dengan kata lain, praktek rent seeking tidak hanya sekedar persekongkolan antara aktor pemerintah dengan aktor swasta, tetapi terdapat variasi lain yaitu terkait korupsi government enterprise.

Government enterprise berbeda dengan privat enterprise. Sebagai sebuah perusahaan yang dimiliki dan dikelola oleh pemerintah, maka pejabat pemerintah memiliki kontrol yang penuh terhadap keseluruhan tata kelola perusahaan. Hal ini dapat membuka peluang politik bagi pemerintah untuk menyalahgunakan kekuasaan tersebut. Pokok penting yang menjadi pembeda adalah perusahaan pemerintah perlu mendapat intervensi dari keputusan politik secara formal melalui pembentukan hukum yang dibuat oleh pejabat politik.

Di sisi lain, government enterprise lebih menekankan pada fungsi mengoptimalkan public service delivery. Oleh karena itu, secara ideal terdapat beberapa kriteria yang harus dimiliki oleh perusahaan pemerintah, yaitu Clarity (pemahaman yang jelas terkait maksud dan tujuan pembentukan perusahaan pemerintah), Capacity (kepemilikan sumber daya untuk menjalankan perusahaan), Capability (ditopang oleh keahlian dan pengalaman yang relevan dalam mengelola perusahaan), dan Commitment to integrity (komitmen yang besar untuk melayani kepentingan publik) (Sturesson et al., 2015).

Namun dalam konteks pengelolaan perusahaan pemerintah di PT BGD, justru memunculkan praktik korupsi melalui rent seeking. Perusahaan tidak memenuhi prasyarat ideal pembentukan perusahaan pemerintah. Pada aspek clarity, PT BGD belum memiliki maksud dan tujuan yang jelas. Hal ini dapat dilihat dari belum jelasnya core bisnis yang menjadi tumpuan PT BDG. Pada aspek kapabilitas menunjukkan kontradiksi, sebab pimpinan tertinggi PT BGD adalah orang-orang yang memiliki kedekatan secara politik dengan elit politik sehingga menyampingkan standar keahlian dan pengalaman yang diperlukan dalam mengelola perusahaan. Aspek komitmen untuk integritas belum terealisasi. Praktik korupsi, penggelapan anggaran, akuntabilitas dan transparansi keuangan yang rendah, menegaskan bahwa indikator ideal government enterprise tidak tercapai di PT BGD.

Apabila diuraikan secara lebih detail, maka pola praktik rent seeking yang berujung pada tindakan korupsi, kolusi, dan nepotisme dalam pengelolaan BUMD PT BGD dapat dilihat pada gambar dibawah ini:

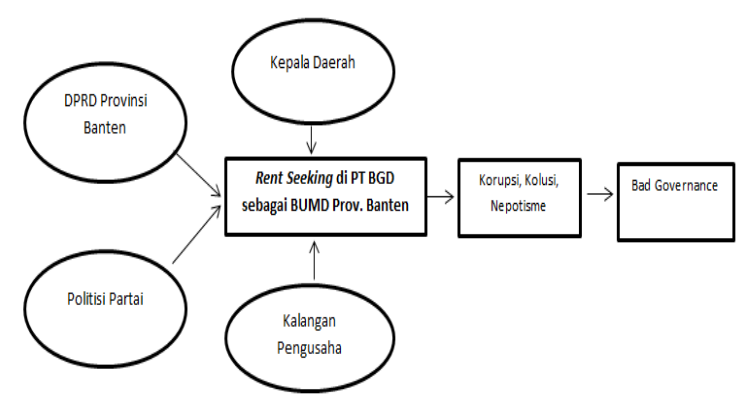

Gambar 1 Pola Rent Seeking di Tubuh BUMD PT BGD

Gambar diatas menjelaskan praktik rent seeking dalam pengelolaan PT BGD sebagai BUMD Provinsi Banten. Praktik ini melibatkan berbagai arena dan aktor yang berkelindan di dalamnya yaitu Kepala Daerah, DPRD, Politisi Partai dan kalangan pengusaha. Rent seeking tidak hanya dipahami secara sempit sebatas pada perburuan rente dalam bentuk materi tetapi dapat dikonversi dalam bentuk lain seperti politik balas budi dengan menempatkan loyalis kepala daerah sebagai pimpinan PT BGD atau kemudahan terbentuknya sebuah regulasi atau produk kebijakan tertentu yang menguntungkan segelintir elit, dan sebagainya.

Implikasi dari rent seeking ini menyebabkan pengelolaan PT BGD sebagai sebuah BUMD tidak menunjukkan performa yang berkualitas sehingga berdampak pada hadirnya praktek bad governance yang berujung pada tidak efektifnya perusahaan PT BGD dalam memaksimalkan fungsi pelayanan publik. Dengan kata lain, PT BGD adalah modus bagi aktor politik dan aktor swasta untuk berburu rente.

\section{SIMPULAN}

Praktik korupsi di tubuh BUMD merupakan implikasi dari hadirnya relasi kekuasaan politik dan pengusaha yang bekerja dalam logika rent seeking. Hal ini nampak pada pembentukan PT BGD sebagai BUMD milik Pemprov Banten. Dengan dalih menambah pemasukan PAD dan menggerakkan perekonomian untuk pembangunan dan kesejahteraan masyarakat Banten, pembentukan PT BGD ternyata hanyalah modus untuk memanfaatkan APBD Banten. Implikasinya, PT BGD merepresentasikan konfigurasi kepentingan ekonomi politik yang dijalankan oleh berbagai aktor yaitu kepala daerah, DPRD, politisi partai politik, dan kalangan pengusaha.

Praktik rent seeking berkontribusi terhadap buruknya tata kelola BUMD PT BGD yang terus mengalami kerugian. Meski terbukti tidak berhasil menciptakan pembangunan di Banten, namun keberadaan BUMD PT BGD tetap dipertahankan sebab ada kepentingan politik yang menyertainya yaitu perburuan rente. Perburuan rente yang dimaksud dalam artikel ini 
ternyata tidak selalu berkaitan dengan pencarian keuntungan materi secara ilegal, tetapi juga dalam bentuk lainnya yaitu politik balas budi dan manipulasi kebijakan yang dapat menguntungkan segelintir elit. Pola rent seeking yang terbentuk adalah "rent seizing" yaitu state actors berusaha mendapatkan hak mengalokasikan rente yang dihasilkan dari institusi-institusi negara dalam hal ini BUMD PT BGD untuk kepentingan individu dan kelompoknya. Disaat yang bersamaan, perusahaan memperoleh keuntungan dari kebijakan yang dibuat oleh elit politik dengan cara menyuap dan cara lain yang melanggar konstitusi. Namun perusahaan yang dimaksud adalah perusahaan milik pemerintah

Sebagai sebuah saran, artikel ini memandang pentingnya pengelolaan BUMD yang menekankan aspek akuntabilitas, transparansi, dan partisipasi. Kehadiran civil society yang kuat dan otonom, juga diperlukan untuk ikut serta mengawasi kinerja BUMD, termasuk pihak-pihak yang terlibat di dalamnya. Selain itu, penegakan hukum yang konsisten, adil, dan bertanggung jawab perlu dioptimalkan terhadap aktor (pelaku) yang terbukti melakukan penyalahgunaan kekuasaan.

\section{DAFTAR PUSTAKA}

Agustino, L. (2010). Dinasti Politik Pasca-Otonomi Orde Baru: Pengalaman Banten. Prisma, 29, 102-116.

Bantenhits.com. (2015). Rano Karno Pecat hilman Nitiamidjaja dari Komisaris PT BGD. https:// bantenhits.com/2015/05/26/rano-karno-pecathilman-nitiamidjaja-dari-komisaris-pt-bgd/

Beritasatu.com. (2015a). Banten Global Development Alami Potensi Kerugian Rp. 20,3 Miliar.https:// www.beritasatu.com/whisnu-bagus-prasetyo/ nasional/263587/banten-global-developmentalami-potensi-kerugian-rp-203-miliar

Beritasatu.com. (2015b). Mengenal PT BGD yang Bertugas Mendirikan Bank Banten. https:// www.beritasatu.com/heru-andriyanto/ nasional/326933/mengenal-pt-bgd-yangbertugas-mendirikan-bank-banten

Beritasatu.com. (2015c). Pembentukan Bank Banten Bermasalah Sejak Awal. https:// www.beritasatu.com/heru-andriyanto/ nasional/326931/pembentukan-bank-bantenbermasalah-sejak-awal

Creswell. (2014). Penelitian Kualitatif \& Desain Riset (3rd ed.). Yogyakarta: Pustaka Pelajar.

Evaquarta, R. (2010). Bisnis dan Politik di Tingkat Lokal dalam Era Otonomi Daerah: banyak studi yang dilakukan untuk. Studi Politik Edisi, $I(1), 8-22$.

Faktabanten.co.id. (2020). Dewan Banten Pertanyakan Kepemilikan Saham PT BGD di Sejumlah Perusahaan. https://faktabanten. co.id/blog/2020/10/09/dewan-bantenpertanyakan-kepemilikan-saham-pt-bgd-disejumlah-perusahaan/

Girling, J. (1997). Corruption, Capitalism and Democracy. London: Routledge.

Grafton, R. Q., \& Williams, J. (2020). Rent-seeking behaviour and regulatory capture in the Murray-Darling Basin, Australia. International Journal of Water Resources Development, 36(2-3), 484-504. https://doi.org/10.1080/079 00627.2019.1674132

Gresnews.com. (2015). Pendirian Bank Banten Tercemar Korupsi. http://www.gresnews.com/ berita/hukum/102258-pendirian-bank-bantentercemar-korupsi/

Hamid, A. (2014). A Family Matter: Political Corruption in Banten, Indonesia. Asian Politics and Policy, 6(4), 577-593.

Hogan, J., Murphy, G., \& Chari, R. (2011). Regulating the Influence Game in Australia. Australian Journal of Politics and History, 57(1), 102-113. https://doi.org/10.1111/j.14678497.2011.01585.x

Iskandar, I. S., \& Kurniawan, T. (2020). Gratifikasi di Badan Usaha Milik Negara Berdasarkan Motif Kecurangan: Sebuah Tinjauan Literatur. Jurnal Ilmu Pemerintahan, 5(2). https://doi. org/10.14710/jiip.v5i2.7690

Jauhar, U. N. A. (2015). Mengenal PT BGD Pelaksana Pembentukan Bank Banten. https://www.kompasiana.com/ djibrieljd/566bd89ecf7a61870a96345b/ mengenal-pt-bgd-pelaksana-pembentukanbank-banten

Lambsdorff, J. G. (2002). Corruption and Rent Seeking. Public Choice, 13(1). https://doi. org/10.1023/A

Mahpudin. (2018). Dinamika Koalisi Partai Politik dalam Pencalonan Kepala Daerah pada Pilkada Banten 2017. Sultan Ageng Tirtayasa.

Nazir. (2003). Metode Penelitian. Jakarta: Salemba Empat.

Ross, M. (2001). Timber Booms And Institutional Breakdown In Southeast Asia. Cambridge University Press. 
Saleh, \& Perdana. (2009). Praktik Rent Seeking Dan Relasi Negara Dengan Kapital (Studi Kasus Korupsi Pemberian Izin Usaha Pertambangan Nikel Oleh Gubernur Nur Alam Di Provinsi Sulawesi Tenggara). Jurnal Analisis Kebijakan, 3(1), 76-84.

Samsuddin, Gunawan, \& Sasmito. (2019). Membongkar Relasi Kekuasaan Oligarki Di Kota Batu: Studi Kasus Penyalahgunaan Kekuasaan Dalam Pemberian Keringanan Pajak Dan Korupsi Kebijakan PT BWR. Jurnal Ilmu Administrasi, 16(2), 210-227.

Sturesson, J., McIntyre, S., \& Jones, N. C. (2015). State-Owned Enterprises: Catalysts for public value creation? PwC Insights, April, 47. www. psrc.pwc.com
Suara.com. (2018). Kadin Banten Nilai Bank Banten Hanya Dinikmati Pengusaha Luar. https://www.suara.com/partner/content/ bantenhits/2018/04/10/105335/kadin-nilaibank-banten-hanya-dinikmati-pengusaha-luar

Suarabanten.com. (2020). Baru 2 Tahun Bebas, Mantan Direktur BGD Kembali Ditahan. https://suarabantennews.com/2020/07/24/ baru-2-tahun-bebas-mantan-direktur-bgdkembali-ditahan/

Wanmedia.co.id. (2020). Perkumpulan Urang Banten Gelar Fokus FGD Bank Banten. https:// wanmedia.co.id/perkumpulan-urang-bantengelar-focus-group-discussion-fgd-bankbanten $/ \% 0 \mathrm{~A} \% 0 \mathrm{~A}$ 